\title{
Author Correction: A global database for metacommunity ecology, integrating species, traits, environment and space
}

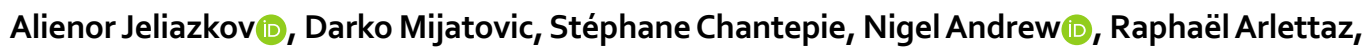
Luc Barbaro $\mathbb{D}$, Nadia Barsoum, Alena Bartonova $\mathbb{D}$, Elena Belskaya, Núria Bonada $\mathbb{D}$, Anik Brind'Amour, Rodrigo Carvalho $\mathbb{D}$, Helena Castro $\mathbb{D}$, Damian Chmura $\mathbb{D}$, Philippe Choler,

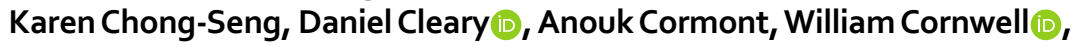
Ramiro de Campos Dicole de Voogd, Sylvain Doledec (D, Joshua Drew, Frank Dziock, Anthony Eallonardo, Melanie J. Edgar D, Fábio Farneda (D, Domingo Flores Hernandez, Cédric Frenette-Dussault, Guillaume Fried (D), Belinda Gallardo D, Heloise Gibb,

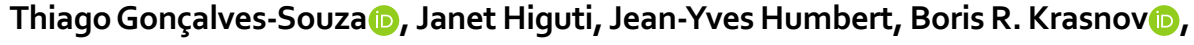
Eric Le Saux, Zoe Lindo $\mathbb{D}$, Adria Lopez-Baucells $\mathbb{D}$, Elizabeth Lowe, Bryndis Marteinsdottir, Koen Martens (D), Peter Meffert, Andres Mellado-Díaz (D, Myles H. M. Menz,

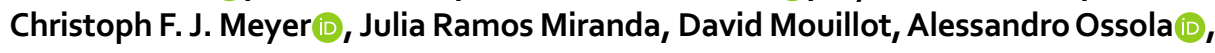
Robin Pakeman, Sandrine Pavoine, Burak Pekin, Joan Pino, Arnaud Pocheville $\mathbb{D}$,

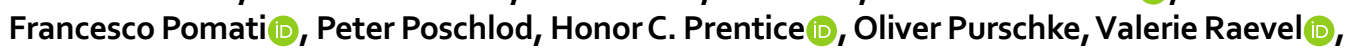
Triin Reitalu, Willem Renema, Ignacio Ribera $\mathbb{D}$, Natalie Robinson, Bjorn Robroek (D), Ricardo Rocha D, Sen-Her Shieh, Rebecca Spake, Monika Staniaszek-Kik, Michal Stanko,

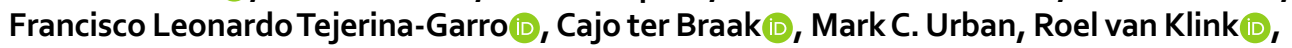
Sébastien Villéger $(\mathbb{D}$, Ruut Wegman, Martin J. Westgate $\mathbb{D}$, Jonas Wolff $(\mathbb{D}$, Jan Żarnowiec, Maxim Zolotarev \& Jonathan M. Chase

Correction to: Scientific Data https://doi.org/10.1038/s41597-019-0344-7, published online 08 January 2020

Following publication of this Data Descriptor it was found that the affiliation of Oliver Purschke was stated incorrectly. The correct affiliations are stated below:

Department of Physical Geography and Ecosystem Science, Lund University, Sölvegatan 37, SE-223 62 Lund, Sweden

Biodiversity, Department of Biology, Lund University, Sölvegatan 37, SE-223 62 Lund, Sweden

This has been corrected in both the HTML and PDF versions.

(c) (i) Open Access This article is licensed under a Creative Commons Attribution 4.0 International License, which permits use, sharing, adaptation, distribution and reproduction in any medium or format, as long as you give appropriate credit to the original author(s) and the source, provide a link to the Creative Commons license, and indicate if changes were made. The images or other third party material in this article are included in the article's Creative Commons license, unless indicated otherwise in a credit line to the material. If material is not included in the article's Creative Commons license and your intended use is not permitted by statutory regulation or exceeds the permitted use, you will need to obtain permission directly from the copyright holder. To view a copy of this license, visit http://creativecommons.org/licenses/by/4.0/.

(c) The Author(s) 2020 